\title{
TRITIUM, STABLE ISOTOPES, AND NITROGEN IN FLOW FROM SELECTED SPRINGS THAT DISCHARGE TO THE SNAKE RIVER, TWIN FALLS-HAGERMAN AREA, IDAHO, 1990-93
}

By Larry J. Mann and Walton H. Low

U.S. GEOLOGICAL SURVEY

Water-Resources Investigations Report 94-4247

Prepared in cooperation with the U.S. DEPARTMENT OF ENERGY

Idaho Falls, Idaho December 1994 


\section{U.S. DEPARTMENT OF THE INTERIOR}

\section{BRUCE BABBITT, Secretary}

\section{U.S. GEOLOGICAL SURVEY}

Gordon P. Eaton, Director

Any use of trade, product, or firm names is for descriptive purposes only and does not imply endorsement by the U.S. Government.

For additional information write to:

Project Office

U.S. Geological Survey

INEL, MS 4148

P.O. Box 2230

Idaho Falls, ID 83403
Copies of this report can be purchased from:

U.S. Geological Survey

Earth Science Information Center

Open-File Reports Section

Box 25286, Mail Stop 517

Denver Federal Center

Denver, CO 80225 


\section{CONTENTS}

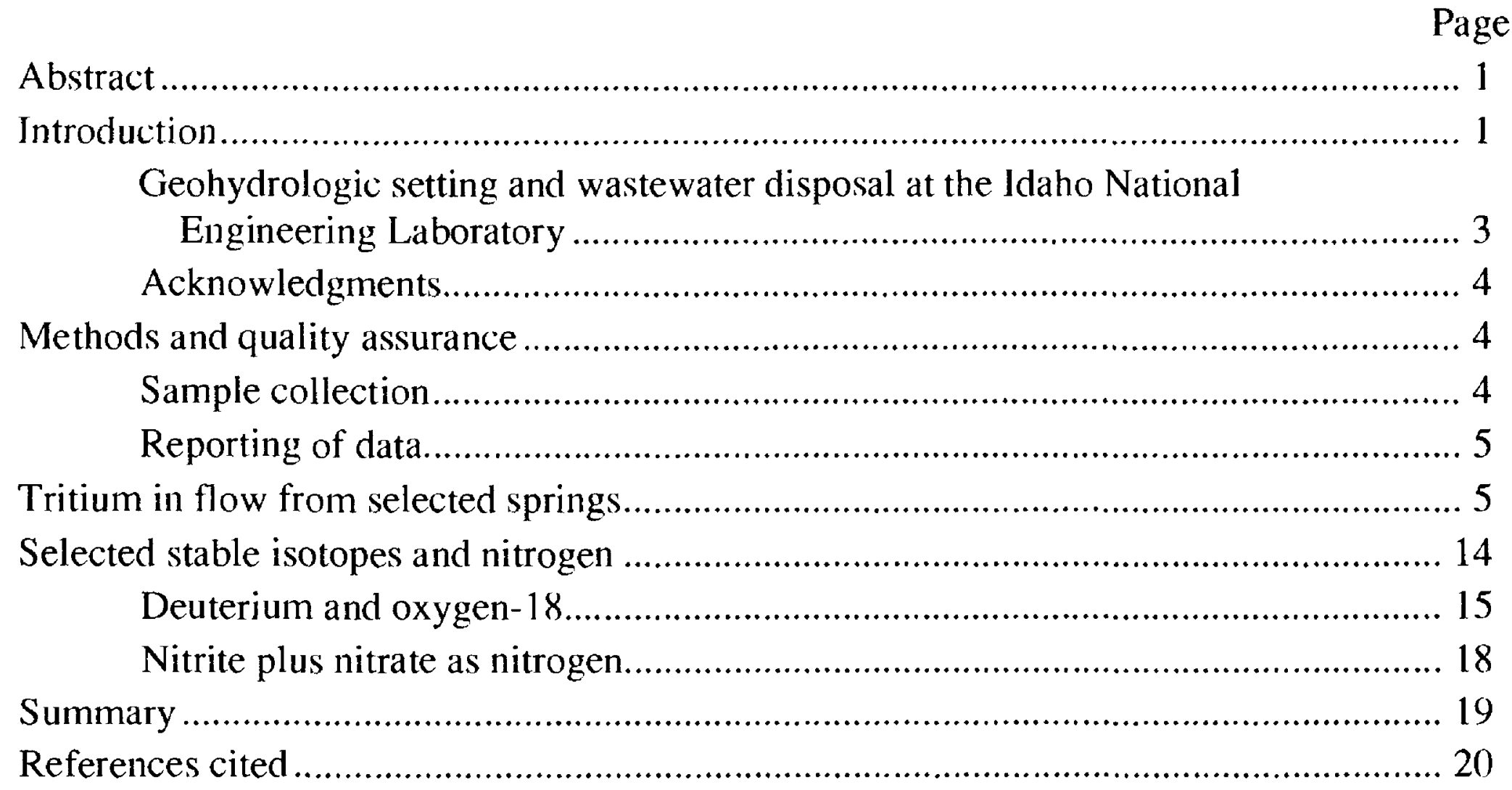

\section{FIGURES}

Figure 1. Map showing locations of the eastern Snake River Plain, Twin Falls-Hagerman area, and Idaho National Engineering Laboratory, and generalized direction of ground-water flow in the Snake River Plain aquifer ....................................... 2

2. Graph showing calculated concentrations of tritium in precipitation at Dubois, Idaho National Engineering Laboratory (INEL), and Shoshone as a result of the atmospheric testing of nuclear weapons and natural production ................... 6

3. Map showing locations of springs at which water samples were collected for tritium analyses, Twin Falls-Hagerman area, Idaho

4. Graph showing deuterium and oxygen-18 isotopic ratios in water from selected springs, Twin Falls-Hagerman area, ldaho

\section{TABLES}

Table 1. Springs at which water samples were collected for tritium analyses,

Twin Falls-Hagerman area, Idaho 6

2. Physical and chemical characteristics of and tritium concentrations in water from selected springs in the Twin Falls-Hagerman area, Idaho 8

3. Stable-isotope ratios in water from selected springs, Twin Falls-Hagerman area, Idaho

4. Concentrations of nitrite plus nitrate as nitrogen in water from selected springs, Twin Falls-Hagerman area, Idaho. 


\section{CONVERSION FACTORS AND ABBREVIATED UNITS}

Multiply

inch (in.)

foot (ft)

mile (mi)

acre

square mile $\left(\mathrm{mi}^{2}\right)$

acre-foot (acre-ft)

cubic foot per second

curie (Ci)

picocurie per liter $(\mathrm{pCi} / \mathrm{L})$

\section{By}

25.4

0.3048

1.609

0.4047

2.590

0.001233

0.02832

$3.7 \times 10^{30}$

0.037
To obtain

millimeter ( $\mathrm{mm}$ )

meter

kilometer

hectare

square kilometer

cubic hectometer

cubic meter per second

becquerel

becquerel per liter

For temperature, degrees Celsius $\left({ }^{\circ} \mathrm{C}\right)$ may be converted to degrees Fahrenheit $\left({ }^{\circ} \mathrm{F}\right)$ by using the equation: ${ }^{\circ} \mathrm{F}=(1.8)\left({ }^{\circ} \mathrm{C}\right)+32$.

Abbreviated units used in report: $\mathrm{mL}$ (milliliter); $\mathrm{mg} / \mathrm{L}$ (milligram per liter). 


\title{
Tritium, Stable Isotopes, and Nitrogen in Flow from Selected Springs that Discharge to the Snake River, Twin Falls-Hagerman Area, Idaho, 1990-93
}

\author{
By Larry J. Mann and Walton H. Low
}

\begin{abstract}
In 1990-93, tritium concentrations in water from 19 springs along the north side of the Snake River near Twin Falls and Hagerman ranged from $9.2 \pm 0.6$ to $78.4 \pm 5.1$ picocuries per liter $(\mathrm{pCi} / \mathrm{L})$. The springs were placed into three categories on the basis of their locations and tritium concentrations: Category I springs are the farthest upstream and contained from $52.8 \pm 3.2$ to $78.4 \pm 5.1 \mathrm{pCi} / \mathrm{L}$ of tritium; Category II springs are downstream from those in Category I and contained from 9.2 \pm 0.6 to $18.5 \pm 1.2 \mathrm{pCi} / \mathrm{L}$; and Category III springs are the farthest downstream and contained from $28.3 \pm 1.9$ to $47.7 \pm 3.2 \mathrm{pCi} / \mathrm{L}$.
\end{abstract}

Differences in tritium concentrations in Category I, II, and III springs are a function of the ground-water flow regimes and land uses in and hydraulically upgradient from each category of springs. A comparatively large part of the water from the Category I springs is from excess applied-irrigation water which has been diverted from the Snake River. A large part of the recharge for Category II springs originates as many as 140 miles upgradient from the springs. Tritium concentrations in Category III springs indicate that the proportion of recharge from excess applied-irrigation water is intermediate to proportions for Category I and II springs.

Tritium concentrations in precipitation and in the Snake River were relatively large in the 1950 's and 1960 's owing to atmospheric testing of nuclear weapons. Conversely, tritium concentrations in ground water with a residence time of several tens to a few hundred years, as occurs in the Snake River Plain aquifer hydraulically upgradient from the Category II springs, are comparatively small because of the 12.4-year half-life of tritium.

The conclusion that recharge from excess applied-irrigation water from the Snake River has affected tritium in the Snake River Plain aquifer is supported by differences in the deuterium $\left({ }^{2} \mathrm{H}\right)$ and oxygen-18 $\left({ }^{18} \mathrm{O}\right)$ ratios of water. These ratios indicate that water discharged by the springs is recharged by waters of different origins. Irrigation recharge is more enriched in ${ }^{2} \mathrm{H}$ and ${ }^{18} \mathrm{O}$ than the regional ground water. Water from Category I springs is more enriched in ${ }^{2} \mathrm{H}$ and ${ }^{18} \mathrm{O}$ than is water from Category II or III springs because a large proportion of irrigation recharge mixes with the regional ground water in Category I springs. Nitrite plus nitrate as nitrogen concentrations also are greater in water from Category I springs than in water from Category II springs.

\section{INTRODUCTION}

Concern has been expressed that some of the approximately $31,000 \mathrm{Ci}$ of tritium discharged to the Snake River Plain aquifer from 1952 to 1990 at the Idaho National Engineering Laboratory (INEL) has migrated or will migrate to the Snake River in the Twin Falls-Hagerman area (fig. 1). Analyses of water samples collected in 1989 from 19 springs on the north side of the Snake River in the Twin Falls-Hagerman area indicated 


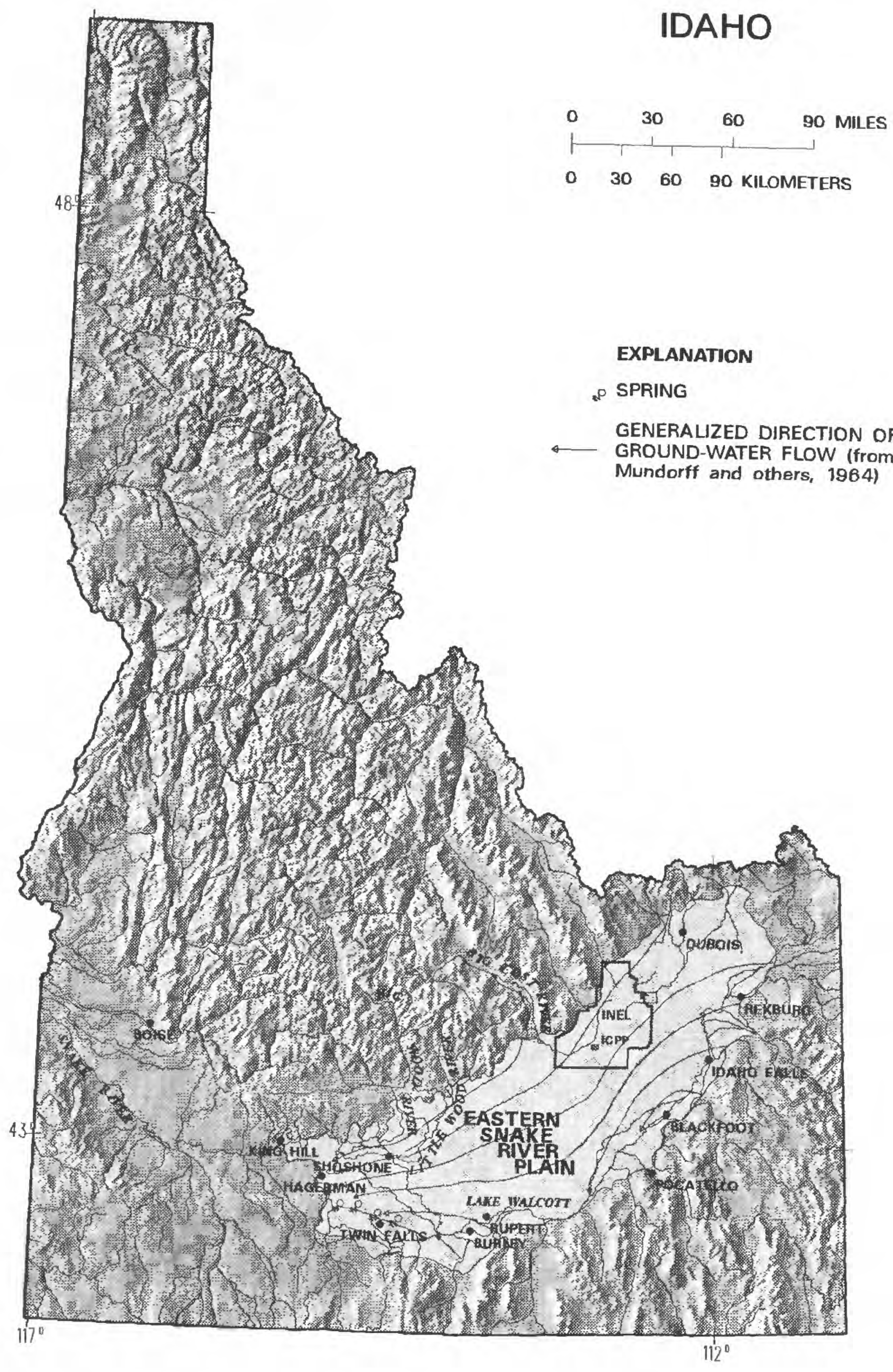

Figure 1. Locations of the eastern Snake River Plain, Twin Falls-Hagerman area, and Idaho National Engineering Laboratory, and generalized direction of ground-water flow in the Snake River Plain aquifer 
that the tritium concentrations were less than or equal to $200 \pm 200 \mathrm{pCi} / \mathrm{L}$ (Mann, 1989 , p. 13). Additionally, analyses of samples by the U.S. Environmental Protection Agency indicated a slight decrease in tritium concentrations in the Snake River near Buhl since the 1970's owing to the radioactive decay of tritium produced by atmospheric testing of nuclear weapons in the 1950's and 1960's (Mann, 1989, p. 14). After analyses of the 1989 samples, a long-term program to monitor tritium concentrations in the spring flow was established by the U.S. Geological Survey (USGS) in cooperation with the U.S. Department of Energy.

Because the 1989 samples had tritium concentrations that were less than or equal to $200 \pm 200 \mathrm{pCi} / \mathrm{L}$, samples collected from the 19 springs in 1990-93 were analyzed using an electrolytic-enrichment, gas-counting method. This method primarily is limited to the analyses of samples that contain concentrations of tritium between 0.2 and $100 \mathrm{pCi} / \mathrm{L}$ (Pritt and Jones, 1989, p. 5-19). In contrast, the method and counting time used to analyze the 1989 samples could not detect concentrations less than $200 \mathrm{pCi} / \mathrm{L}$.

This report documents tritium concentrations in spring-flow samples collected in 1990-93 in the Twin Falls-Hagerman area and discusses why the concentrations differ in different areas. It also presents stable-isotope ratios and concentrations of nitrate plus nitrite as nitrogen in water from selected springs and discusses relations between these and concentrations of tritium. The electrolyticenrichment, gas-counting method of analysis was selected to document concentrations resulting from natural tritium production and from atmospheric testing of nuclear weapons. Analyses of samples collected in 1990-93 will serve as a baseline to quantitatively document whether tritiated water discharged to the aquifer at the INEL has a measurable, long- term effect on tritium concentrations in spring flow.

\section{Geohydrologic Setting and Wastewater Disposal at the Idaho National Engineering Laboratory}

The eastern Snake River Plain is a northeast-trending structural basin about $200 \mathrm{mi}$ long and 50 to $70 \mathrm{mi}$ wide. The plain is underlain by a layered sequence of basaltic lava flows and cinder beds intercalated with alluvium and lakebed sedimentary deposits. Individual lava flows generally range from 10 to $50 \mathrm{ft}$ in thickness, although the average thickness may be from 20 to $25 \mathrm{ft}$ (Mundorff and others, 1964, p. 143). The sedimentary deposits consist mainly of lenticular beds of sand, silt, and clay with lesser amounts of gravel. Locally, rhyolitic lava flows and tuffs are exposed at the land surface or occur at depth. The basaltic lava flows and intercalated sedimentary deposits combine to form the Snake River Plain aquifer, which is the main source of ground water on the plain.

The Snake River Plain aquifer is recharged by the infiltration of precipitation and irrigation water, and by underflow from tributary valleys on the perimeter of the plain. Water recharged to the aquifer generally moves southwestward along the axis of the plain and is discharged to springs along the Snake River (fig. 1).

In 1980, about 1.33 million acres of land were irrigated on the eastern Snake River Plain (Garabedian, 1986, p. 7). About 8.6 million acre- $\mathrm{ft} / \mathrm{year}$ of water were diverted for irrigation from the Snake River and its tributaries (Garabedian, 1989, fig. 8). From the 1902 to the 1980 water years, discharge to springs along the north side of the Snake River increased from about 3.1 million to about 4.3 million acre-ft/year as a result of increased recharge to the Snake River Plain aquifer from the infiltration of irrigation water (Kjelstrom, 1992, fig. 27); a water year 
begins in October and ends in September the following year and is designated by the year in which it ends.

The INEL includes about $890 \mathrm{mi}^{2}$ of the northeastern part of the eastern Snake River Plain and is about $100 \mathrm{mi}$ northeast of Twin Falls and about $110 \mathrm{mi}$ northeast of Hagerman. The general direction of groundwater movement in the Snake River Plain aquifer is southwestward. Ground water from the INEL moves in this southwestward direction and is discharged to springs in the Twin Falls-Hagerman area (fig. 1). Tritiated water and other aqueous wastes were discharged to wells and ponds in the southcentral part of the INEL from 1952 to February 1984; much of these aqueous wastes was injected directly into the aquifer through a deep disposal well. The disposal of tritium in wastewater at the INEL for 1952-88 is described by Mann and Cecil (1990). From February 1984 to 1993 , most of the aqueous wastes were discharged to unlined infiltration ponds. Wastewater discharged to ponds recharges the aquifer after percolating through about $450 \mathrm{ft}$ of basalt and sediment that overlie the aquifer.

Tritium has migrated at least $9 \mathrm{mi}$ southwest of the disposal areas at the INEL (Orr and Cecil, 1991). Tritium, which is one of the most mobile constituents in wastewater discharged to the aquifer, was detected periodically in 1983-86 at concentrations of $3,400 \pm 200 \mathrm{pCi} / \mathrm{L}$ or less in water from two wells along the southern boundary of the INEL. Since April 1986, tritium concentrations in water from wells along the southern boundary have been less than the method detection limit of $500 \mathrm{pCi} / \mathrm{L}$.

\section{Acknowledgments}

The authors gratefully acknowledge the following employees of the USGS who collected the water samples, measured spring flow, and made field measurements of $\mathrm{pH}$, specific conductance, and temperature: R.L. Backsen, R.C. Bartholomay, C.L. Bowers, T.S. Brennan, M.D. Campbell, K.L. Hein, M.A. Nolevanko, and B.J. Tucker. A special debt of gratitude is owed to Warren Barrash, Hydrogeologist, Boise State University, Boise, Idaho, and B.R. Orr, Hydrologist, USGS, Idaho Falls, Idaho for their review and constructive comments of this report.

\section{METHODS AND QUALITY ASSURANCE}

Methods used to collect water samples for tritium analyses generally followed guidelines established by the USGS (Wood, 1976; Thatcher and others, 1977; and Skougstad and others, 1979). Sampling methods used in the field and the method used to report tritium concentrations are outlined in the following sections. Sample collection for stable isotopes are part of the USGS's routine data-collection activities and follow guidelines cited above.

\section{Sample Collection}

Water samples for tritium analyses were collected in $500-\mathrm{mL}$ polyethylene bottles and were not treated prior or subsequent to being bottled in the field. Water from the springs was collected as close as reasonably possible to the spring orifices. Some springs had multiple orifices or the flow was diverted for use by fish hatcheries. Where possible, the samples were collected upstream from diversions. The $500-\mathrm{mL}$ polyethylene bottle was lowered by hand in the area of the orifice or in the channel downstream from the orifice(s); where flow was channeled, care was taken to sample moving water instead of water in eddies and ponded areas. The bottle was rinsed at least three times with spring water prior to sample collection. After collection, the bottle immediately was capped, and the exterior was dried; laboratory film was placed around the cap, and a label, that included identification information for the sample, was attached to the bottle. A second sample was collected at each site in 
the event that the first sample was destroyed inadvertently during transport or storage. The samples were placed in a secured vehicle or in the USGS Project Office at the INEL until they were shipped to the USGS National Water Quality Laboratory, Arvada, Colorado.

Physical conditions at the springs during sample collection were recorded in a field logbook and a chain-of-custody record was used to track samples from the time of collection until delivery to the analyzing laboratory. These records are available for inspection at the USGS Project Office at the INEL.

\section{Reporting of Data}

For each tritium concentration, an associated analytical uncertainty, $2 \mathrm{~s}$, is calculated such that there is a 95-percent probability that the true tritium concentration in a sample is in the range of the reported concentration plus or minus the analytical uncertainty. For example, given an analytical result of $18.1 \pm 1.5 \mathrm{pCi} / \mathrm{L}$, there is a 95 -percent probability that the true concentration is in the range of 16.6 to $19.6 \mathrm{pCi} / \mathrm{L}$.

\section{TRITIUM IN FLOW FROM SELECTED SPRINGS}

Tritium is a naturally occurring isotope of hydrogen with a 12.4-year half-life and is produced by reaction of cosmic rays with nitrogen in the upper atmosphere. It also is a radioactive waste product from nuclear powerplant operations, fuel processing, and weapons production and testing. Prior to atmospheric testing of nuclear weapons in the 1950 's and 1960's, the average background tritium concentration in environmental waters from cosmic-ray production was less than $16 \mathrm{pCi} / \mathrm{L}$ (National Council on Radiation Protection and Measurements, 1979). Atmospheric weapons tests markedly increased tritium concentrations in precipitation and surface waters. Tritium concentrations in precipitation at Dubois, INEL, and Shoshone that resulted from the atmospheric testing of nuclear weapons and natural production are shown on figure 2 ; the concentrations were calculated using data from Michel (1989). Mean annual tritium concentrations in precipitation at these locations were less than $75 \mathrm{pCi} / \mathrm{L}$ in 1953 , about $4,000 \mathrm{pCi} / \mathrm{L}$ in 1963 , and less than $37 \mathrm{pCi} / \mathrm{L}$ in 1983 . Concentrations differed at the three locations because of differences in precipitation; the 1953-83 mean annual precipitation at Dubois, the INEL, and Shoshone was about 313,226 , and $260 \mathrm{~mm}$, respectively. In 1963, the mean concentration of tritium in surface water of the United States was about 3,500 pCi/L. By 1990, however, the mean concentration in surface water was about $65 \mathrm{pCi} / \mathrm{L}$ (R.L. Michel, USGS, oral commun., 1992). For the purpose of comparison, the maximum contaminant level for tritium in public drinking-water supplies is $20,000 \mathrm{pCi} / \mathrm{L}$ (U.S. Environmental Protection Agency, 1983, p. 236).

During 1990-93, 19 springs each were sampled from three to five times; locations of the springs are shown on figure 3 and they are listed in downstream order on table 1. For ease of discussion, the springs were placed into three categories on the basis of their locations and tritium concentrations. Category 1 springs include Devils Washbowl, Devils Corral (upper), an unnamed spring upstream from Blue Lakes Spring, Blue Lakes, Warm Creek, and Crystal Springs (fig. 3 and table 1). Tritium concentrations in the flow from these springs are markedly greater than concentrations in flow from downstream springs. Category II springs include Clear Lakes, Briggs Creek, Banbury, an unnamed spring upstream from Blind Canyon Spring, Blind Canyon, Box Canyon, Blue Heart, Sand, Thousand, Bickel, Riley Creek, and 
Table 1.-Springs at which water samples were collected for tritium analyses, Twin FallsHagerman area, Idaho

[Springs are numbered in downstream order; see figure 3 for locations]

\section{Category I Springs}

1 Devils Washbowl

2 Devils Corral (upper)

3 Spring (unnamed)

4 Blue Lakes

5 Warm Creek

6 Crystal

\section{Category II Springs}

7 Clear Lakes

8 Briggs Creek

11 Blind Canyon

12 Box Canyon

13 Blue Heart

14 Sand
15 Thousand

16 Bickel

17 Riley Creek

18 Billingsley Creek

Category III Springs

19 Birch Creek

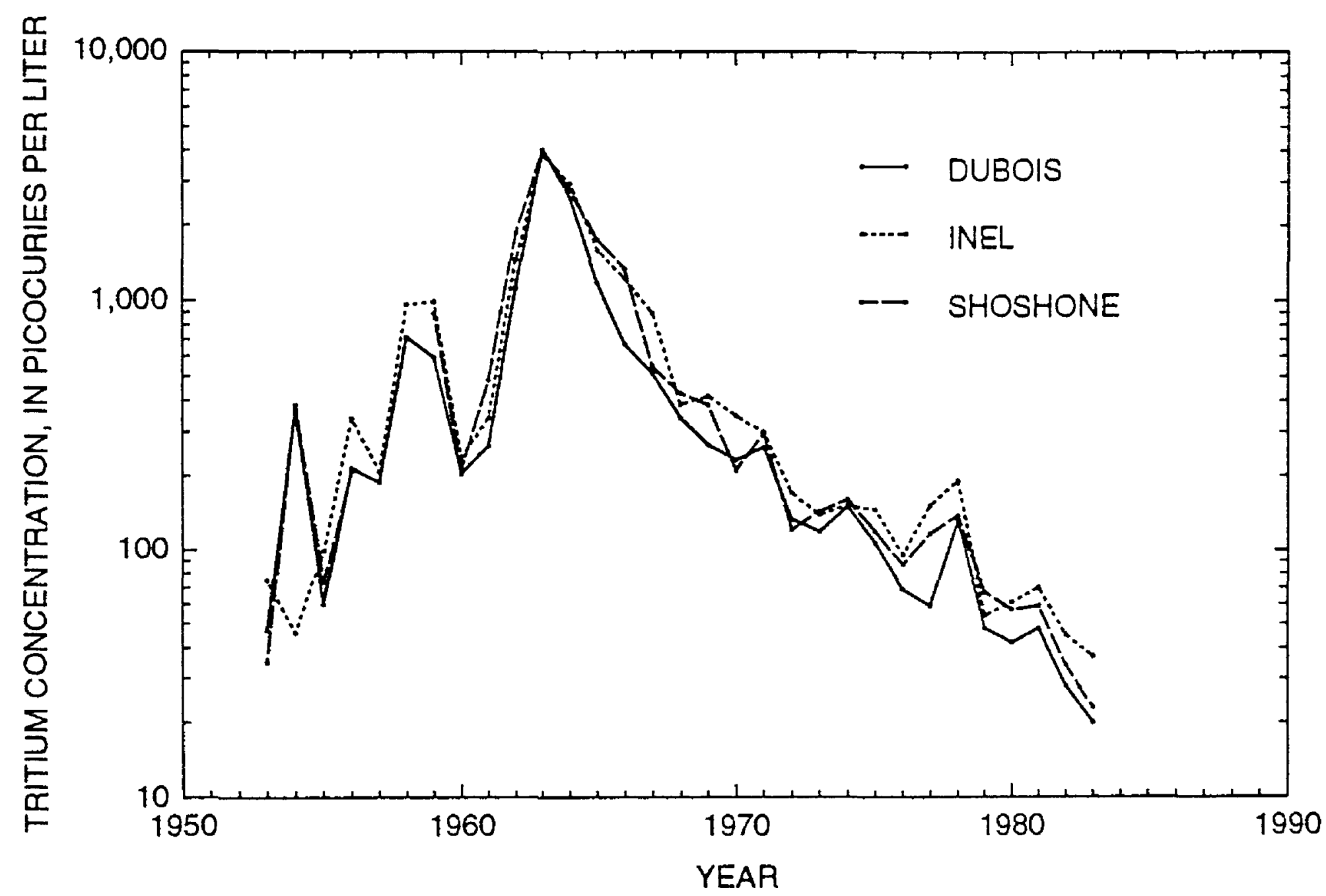

Figure 2. Calculated concentrations of tritium in precipitation at Dubois, Idaho National Engineering Laboratory (INEL), and Shoshone as a result of the atmospheric testing of nuclear weapons and natural production. 


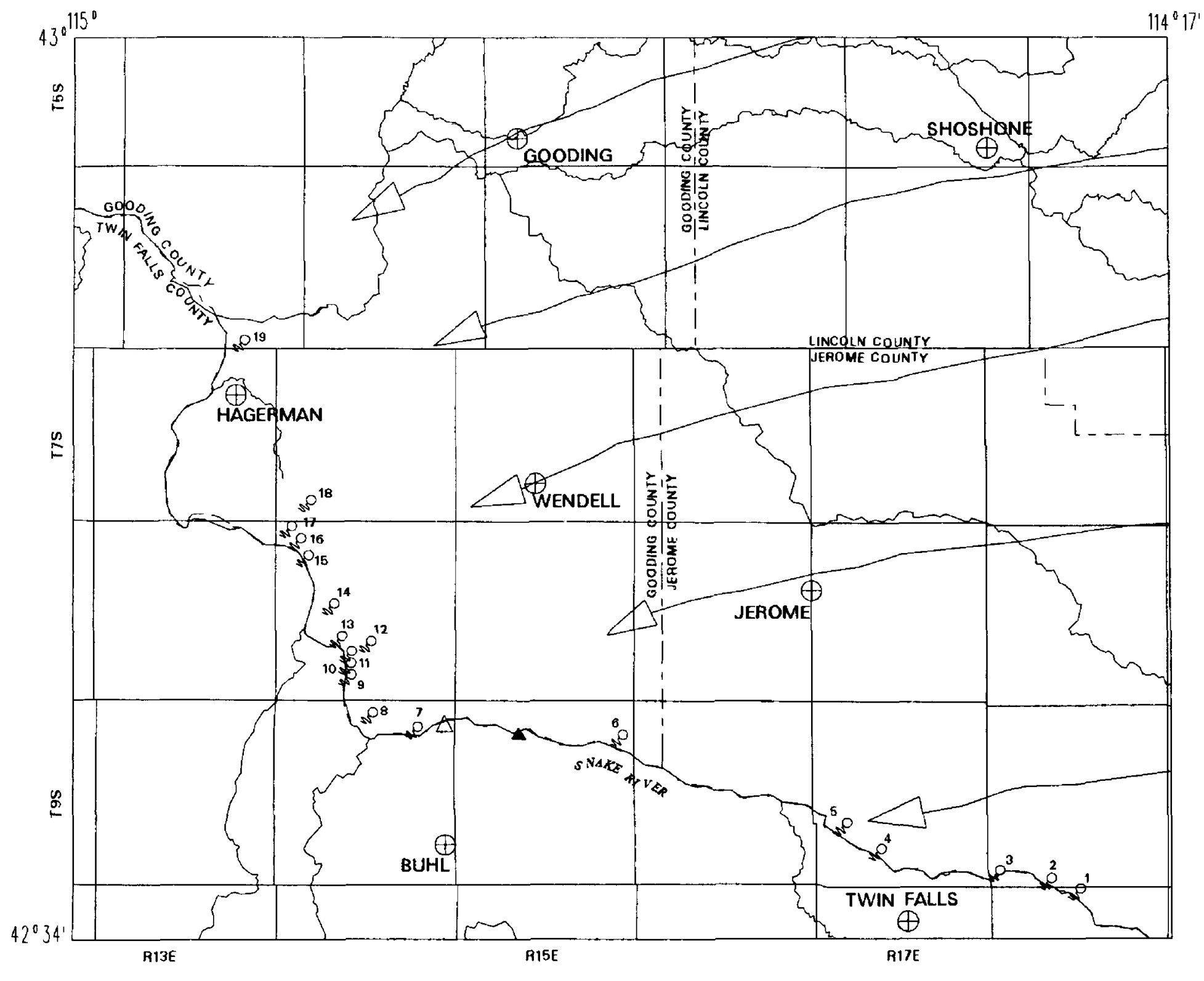

EXPLANATION

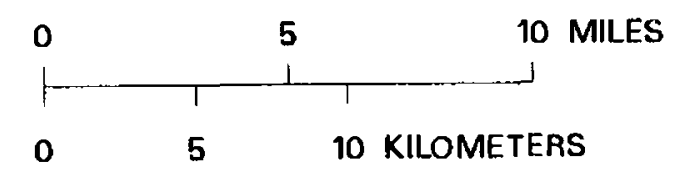

GENERALIZED DIRECTION OF GROUNDWATER MOVEMENT (Modified from

5

10 KILOMETERS

Moreland, 1976)

APPROXIMATE LOCATION OF SPRING.-

Number, 6 , is downstream order number

for spring: see table 2 for name of spring

GAGING STATION ON SNAKE RIVER

- near buhl

SITE AT WHICH TRITIUM SAMPLES ARE

COLLECTED--Samples are collected by

$\triangle$ the Idaho Department of Health and Welfare

and analyzed by the U.S. Environmental

Protection Agency

Figure 3. Locations of springs at which water samples were collected for tritium analyses, Twin Falls-Hagerman area, Idaho. 
Table 2.-Physical and chemical characteristics of and tritium concentrations in water from selected springs in the Twin Falls-Hagerman area, Idaho

[See figure 3 for locations of springs and table 1 for their downstream order. Tritium concentrations and analytical uncertainties determined by U.S. Geological Survey's National Water Quality Laboratory, Arvada, Colorado; analytical uncertainties reported as 2s. Remarks: Replicate indicates a second sample was submitted for analysis with a different identifier. Abbreviation: NM, discharge was not measured]

\begin{tabular}{|c|c|c|c|c|c|c|c|}
\hline Name of spring(s) & $\begin{array}{c}\text { Date } \\
\text { sampled }\end{array}$ & $\begin{array}{l}\text { Discharge } \\
\text { (cubic } \\
\text { feet per } \\
\text { second) }\end{array}$ & $\begin{array}{c}\text { Temper- } \\
\text { ature } \\
\left({ }^{\circ} \mathrm{C}\right)\end{array}$ & $\underset{\text { (units) }}{\mathrm{pH}}$ & $\begin{array}{c}\text { Specific } \\
\text { conductance } \\
\text { (micro- } \\
\text { siemens } \\
\text { per centimeter } \\
\text { at } 25^{\circ} \mathrm{C} \text { ) }\end{array}$ & $\begin{array}{c}\text { Tritium } \\
\text { concentration } \\
\text { and analytical } \\
\text { uncertainty } \\
\text { (picocuries } \\
\text { per liter) }\end{array}$ & Remarks \\
\hline \multirow[t]{4}{*}{ Banbury } & $11 / 6 / 90$ & NM & 13.4 & 8.7 & 424 & $14.7 \pm 1.0$ & \\
\hline & $3 / 19 / 91$ & 105 & 13.2 & 8.3 & 421 & $12.1 \pm 0.8$ & \\
\hline & $3 / 2 / 92$ & 113 & 14.5 & 8.7 & 419 & $12.0 \pm 0.8$ & \\
\hline & $3 / 8 / 93$ & 112 & 14.0 & 8.7 & 410 & $11.9 \pm 0.8$ & \\
\hline \multirow[t]{5}{*}{ Bickel } & $11 / 6 / 90$ & 23.9 & 15.4 & 8.2 & 334 & $15.6 \pm 1.0$ & \\
\hline & $3 / 19 / 91$ & 17.8 & 14.9 & 8.3 & 313 & $12.2 \pm 0.9$ & \\
\hline & $3 / 3 / 92$ & 18.9 & 15.5 & 8.2 & 317 & $12.0 \pm 0.8$ & \\
\hline & & & & & & $12.1 \pm 0.8$ & Replicate \\
\hline & $3 / 10 / 93$ & 15.2 & 14.9 & 8.3 & 334 & $10.3 \pm 0.7$ & \\
\hline \multirow[t]{4}{*}{ Billingsley Creek } & $11 / 6 / 90$ & 46.4 & 12.6 & 7.9 & 359 & $18.1 \pm 1.5$ & \\
\hline & $3 / 18 / 91$ & 29.6 & 13.5 & 8.2 & 350 & $16.5 \pm 1.1$ & \\
\hline & $3 / 3 / 92$ & 26.6 & 13.0 & 7.8 & 349 & $16 \pm 1$ & \\
\hline & $3 / 10 / 93$ & 19.2 & 10.8 & 8.1 & 388 & $14 \pm 1$ & \\
\hline \multirow[t]{4}{*}{ Birch Creek } & $11 / 6 / 90$ & 10.3 & 13.2 & 8.2 & 505 & $47.7 \pm 3.2$ & \\
\hline & $3 / 18 / 91$ & 11.4 & 13.4 & 8.3 & 407 & $35.8 \pm 2.6$ & \\
\hline & $3 / 3 / 92$ & 9.25 & 14.0 & 8.1 & 435 & $34.0 \pm 1.9$ & \\
\hline & $3 / 10 / 93$ & 12.1 & 13.0 & 8.1 & 450 & $28.3 \pm 1.9$ & \\
\hline \multirow[t]{4}{*}{ Blind Canyon } & $11 / 6 / 90$ & 11.2 & 13.8 & 8.5 & 434 & $12.7 \pm 0.8$ & \\
\hline & $3 / 19 / 91$ & 10.8 & 14.0 & 8.4 & 425 & $12.7 \pm 0.8$ & \\
\hline & $3 / 2 / 92$ & 9.77 & 14.0 & 8.4 & 435 & $10.1 \pm 0.8$ & \\
\hline & $3 / 8 / 93$ & 9.01 & 14.5 & 8.6 & 438 & $12.9 \pm 0.8$ & \\
\hline
\end{tabular}


Table 2.-Physical and chemical characteristics of and tritium concentrations in water from selected springs in the Twin Falls-Hagerman area-Continued

\begin{tabular}{|c|c|c|c|c|c|c|c|}
\hline Name of spring(s) & $\begin{array}{c}\text { Date } \\
\text { sampled }\end{array}$ & $\begin{array}{l}\text { Discharge } \\
\text { (cubic } \\
\text { feet per } \\
\text { second) }\end{array}$ & $\begin{array}{c}\text { Temper- } \\
\text { ature } \\
\left({ }^{\circ} \mathrm{C}\right)\end{array}$ & $\underset{\text { (units) }}{\mathrm{pH}}$ & $\begin{array}{l}\text { Specific } \\
\text { conductance } \\
\text { (micro- } \\
\text { siemens } \\
\text { per centimeter } \\
\text { at } 25^{\circ} \mathrm{C} \text { ) }\end{array}$ & $\begin{array}{c}\text { Tritium } \\
\text { concentration } \\
\text { and analytical } \\
\text { uncertainty } \\
\text { (picocuries } \\
\text { per liter) }\end{array}$ & Remarks \\
\hline \multirow[t]{5}{*}{ Blue Heart } & $11 / 6 / 90$ & NM & 14.8 & 7.9 & 398 & $15.8 \pm 1.0$ & \multirow{5}{*}{ Replicate } \\
\hline & $3 / 19 / 91$ & NM & 15.2 & 7.9 & 385 & $11.2 \pm 0.8$ & \\
\hline & & & & & & $12.2 \pm 0.8$ & \\
\hline & $3 / 2 / 92$ & NM & 15.0 & 8.0 & 395 & $11.5 \pm 0.8$ & \\
\hline & $3 / 8 / 93$ & NM & 15.0 & 8.1 & 385 & $9.2 \pm 0.6$ & \\
\hline \multirow[t]{4}{*}{ Blue Lakes } & $11 / 5 / 90$ & 205 & 15.8 & 7.8 & 630 & $65.3 \pm 4.5$ & \\
\hline & $3 / 21 / 91$ & 182 & 15.8 & 7.9 & 627 & $53.1 \pm 3.2$ & \\
\hline & $3 / 2 / 92$ & 172 & 15.2 & 7.6 & 644 & $61.1 \pm 3.8$ & \\
\hline & $3 / 9 / 93$ & 163 & 15.6 & 7.7 & 650 & $55.4 \pm 3.8$ & \\
\hline \multirow[t]{4}{*}{ Box Canyon } & $11 / 2 / 90$ & 383 & 14.1 & 8.2 & 406 & $12.8 \pm 0.8$ & \\
\hline & $3 / 22 / 91$ & 351 & 14.0 & 8.2 & 410 & $14.1 \pm 1.0$ & \\
\hline & $3 / 2 / 92$ & 334 & 14.2 & 7.9 & 408 & $12.8 \pm 0.8$ & \\
\hline & $3 / 8 / 93$ & 321 & 14.3 & 8.0 & 418 & $13.1 \pm 0.9$ & \\
\hline \multirow[t]{5}{*}{ Briggs Creek } & $11 / 2 / 90$ & 117 & 14.2 & 7.7 & 490 & $18.5 \pm 1.2$ & \\
\hline & $3 / 19 / 91$ & 105 & 14.0 & 8.0 & 449 & $16.1 \pm 1.0$ & \\
\hline & $8 / 15 / 91$ & 104 & 15.0 & 8.0 & 498 & $15.4 \pm 0.8$ & \\
\hline & $3 / 2 / 92$ & 100 & 14.0 & 7.9 & 451 & $15.0 \pm 1.3$ & \\
\hline & $3 / 8 / 93$ & 105 & 14.0 & 7.8 & 481 & $13.4 \pm 0.9$ & \\
\hline \multirow[t]{5}{*}{ Clear Lakes } & $11 / 5 / 90$ & 528 & 14.2 & 8.1 & 420 & $16.2 \pm 1.1$ & \\
\hline & $3 / 20 / 91$ & 449 & 14.0 & 8.0 & 448 & $13.5 \pm 0.9$ & \\
\hline & $3 / 2 / 92$ & 456 & 14.0 & 8.1 & 455 & $13.0 \pm 0.9$ & \\
\hline & $3 / 8 / 93$ & 450 & 14.5 & 7.9 & 435 & $11.2 \pm 0.8$ & \\
\hline & & & & & & $12.2 \pm 0.8$ & Replicate \\
\hline
\end{tabular}


Table 2.-Physical and chemical characteristics of and tritium concentrations in water from selected springs in the Twin Falls-Hagerman area-Continued

\begin{tabular}{|c|c|c|c|c|c|c|c|}
\hline Name of spring(s) & $\begin{array}{c}\text { Date } \\
\text { sampled }\end{array}$ & $\begin{array}{l}\text { Discharge } \\
\text { (cubic } \\
\text { feet per } \\
\text { second) }\end{array}$ & $\begin{array}{c}\text { Temper- } \\
\text { ature } \\
\left({ }^{\circ} \mathrm{C}\right)\end{array}$ & $\underset{\text { (units) }}{\mathrm{pH}}$ & $\begin{array}{l}\text { Specific } \\
\text { conductance } \\
\text { (micro- } \\
\text { siemens } \\
\text { per centimeter } \\
\text { at } 25^{\circ} \mathrm{C} \text { ) }\end{array}$ & $\begin{array}{c}\text { Tritium } \\
\text { concentration } \\
\text { and analytical } \\
\text { uncertainty } \\
\text { (picocuries } \\
\text { per liter) }\end{array}$ & Remarks \\
\hline \multirow[t]{6}{*}{ Crystal } & $8 / 16 / 90$ & NM & 14.5 & 8.0 & 690 & $64.3 \pm 3.8$ & \\
\hline & $11 / 7 / 90$ & 452 & 14.7 & 8.1 & 692 & $63.7 \pm 4.5$ & \\
\hline & $3 / 21 / 91$ & 400 & 14.3 & 8.1 & 665 & $60.5 \pm 3.8$ & \\
\hline & $3 / 3 / 92$ & 398 & 14.5 & 8.0 & 660 & $59.0 \pm 3.8$ & \\
\hline & $3 / 9 / 93$ & 429 & 14.3 & 7.7 & 698 & $55.7 \pm 3.8$ & \\
\hline & & & & & & $52.8 \pm 3.2$ & Replicate \\
\hline \multirow[t]{3}{*}{ Devils Corral (upper) } & $3 / 22 / 91$ & 39.8 & 14.2 & 8.2 & 615 & $71.7 \pm 4.5$ & \\
\hline & $3 / 4 / 92$ & 37.4 & 15.0 & 8.0 & 630 & $61.0 \pm 3.8$ & \\
\hline & $3 / 10 / 93$ & 41.1 & 15.0 & 8.1 & 654 & $61.1 \pm 3.8$ & \\
\hline \multirow[t]{4}{*}{ Devils Washbowl } & $11 / 1 / 90$ & 15.4 & 15.0 & 8.0 & 669 & $72.8 \pm 5.1$ & \\
\hline & $3 / 20 / 91$ & 12.2 & 15.1 & 8.6 & 629 & $78.4 \pm 5.1$ & \\
\hline & $3 / 4 / 92$ & 14.4 & 14.0 & 8.3 & 638 & $73.0 \pm 5.1$ & \\
\hline & $3 / 10 / 93$ & 10.2 & 13.0 & 8.4 & 670 & $67.2 \pm 4.5$ & \\
\hline \multirow[t]{4}{*}{ Riley Creek } & $11 / 6 / 90$ & 69.7 & 15.0 & 8.3 & 335 & $17.2 \pm 1.2$ & \\
\hline & $3 / 19 / 91$ & 72.9 & 14.8 & 8.0 & 314 & $14.0 \pm 0.9$ & \\
\hline & $3 / 3 / 92$ & 75.3 & 15.0 & 8.1 & 298 & $13.0 \pm 0.9$ & \\
\hline & $3 / 10 / 93$ & 85.7 & 14.6 & 8.1 & 329 & $10.2 \pm 0.7$ & \\
\hline \multirow[t]{5}{*}{ Sand } & $11 / 7 / 90$ & 99.2 & 14.4 & 7.9 & 386 & $16.2 \pm 1.3$ & \\
\hline & $3 / 19 / 91$ & 76.3 & 14.2 & 7.9 & 385 & $12.3 \pm 0.8$ & \\
\hline & $8 / 13 / 91$ & NM & 14.0 & 7.9 & 410 & $13.6 \pm 0.9$ & \\
\hline & $3 / 2 / 92$ & 74.4 & 14.0 & 7.8 & 380 & $11.0 \pm 0.8$ & \\
\hline & $3 / 10 / 93$ & 64.4 & 14.8 & 7.9 & 379 & $9.3 \pm 0.8$ & \\
\hline
\end{tabular}


Table 2.-Physical and chemical characteristics of and tritium concentrations in water from selected springs in the Twin Falls-Hagerman area-Continued

\begin{tabular}{|c|c|c|c|c|c|c|c|}
\hline Name of spring(s) & $\begin{array}{c}\text { Date } \\
\text { sampled }\end{array}$ & $\begin{array}{c}\text { Discharge } \\
\text { (cubic } \\
\text { feet per } \\
\text { second) }\end{array}$ & $\begin{array}{l}\text { Temper- } \\
\text { ature } \\
\left({ }^{\circ} \mathrm{C}\right)\end{array}$ & $\underset{\text { (units) }}{\mathrm{pH}}$ & $\begin{array}{l}\text { Specific } \\
\text { conductance } \\
\text { (micro- } \\
\text { siemens } \\
\text { per centimeter } \\
\text { at } 25^{\circ} \mathrm{C} \text { ) }\end{array}$ & $\begin{array}{c}\text { Tritium } \\
\text { concentration } \\
\text { and analytical } \\
\text { uncertainty } \\
\text { (picocuries } \\
\text { per liter) }\end{array}$ & Remarks \\
\hline \multirow[t]{5}{*}{ Thousand } & $11 / 6 / 90$ & NM & 14.8 & 8.2 & 366 & $17.9 \pm 1.2$ & \multirow{5}{*}{ Replicate } \\
\hline & $3 / 18 / 91$ & 1320 & 16.8 & 8.3 & 355 & $15.1 \pm 1.0$ & \\
\hline & & & & & & $15.6 \pm 1.0$ & \\
\hline & $3 / 3 / 92$ & 1240 & 14.0 & 8.0 & 365 & $14.9 \pm 1.0$ & \\
\hline & 3/9/93 & 1290 & 14.4 & 8.3 & 373 & $12.3 \pm 0.9$ & \\
\hline \multicolumn{8}{|c|}{$\begin{array}{l}\text { Unnamed springs } \\
\text { above Blind Canyon }\end{array}$} \\
\hline \multirow[t]{4}{*}{ springs } & $11 / 6 / 90$ & 4.87 & 13.5 & 8.5 & 458 & $17.2 \pm 1.2$ & \\
\hline & $3 / 19 / 91$ & 2.42 & 14.1 & 8.5 & 401 & $13.0 \pm 0.8$ & \\
\hline & $3 / 2 / 92$ & 3.40 & 14.0 & 8.5 & 425 & $12.0 \pm 0.8$ & \\
\hline & $3 / 8 / 93$ & 2.19 & 13.5 & 8.6 & 420 & $10.8 \pm 0.7$ & \\
\hline \multicolumn{8}{|c|}{$\begin{array}{l}\text { Unnamed spring } \\
\text { above Blue Lakes }\end{array}$} \\
\hline \multirow[t]{5}{*}{ Spring } & $11 / 8 / 90$ & 5.37 & 12.5 & 8.1 & 526 & $65.0 \pm 4.5$ & \multirow{9}{*}{ Replicate } \\
\hline & $3 / 22 / 91$ & 1.64 & 11.9 & 8.5 & 618 & $62.7 \pm 3.8$ & \\
\hline & $3 / 4 / 92$ & 0.25 & 14.0 & 8.1 & 610 & $57.9 \pm 3.8$ & \\
\hline & & & & & & $58.9 \pm 3.2$ & \\
\hline & $3 / 10 / 93$ & 3.34 & 9.0 & 8.3 & 665 & $58.2 \pm 3.8$ & \\
\hline \multirow[t]{4}{*}{ Warm Creek } & $11 / 5 / 90$ & 25.0 & 13.0 & 8.3 & 656 & $66.8 \pm 4.5$ & \\
\hline & $3 / 21 / 91$ & 25.7 & 15.9 & 7.9 & 602 & $55.7 \pm 3.8$ & \\
\hline & $3 / 4 / 92$ & 18.6 & 14.6 & 7.7 & 618 & $56.3 \pm 3.8$ & \\
\hline & $3 / 9 / 93$ & 27.8 & 14.1 & 7.7 & 662 & $55.0 \pm 3.8$ & \\
\hline
\end{tabular}


Billingsley Creek Springs. Category III consists of Birch Creek Spring, at which the tritium concentration is less than that from Category I springs, but greater than that from Category II springs.

Tritium concentrations in spring flow ranged from $9.2 \pm 0.6$ to $78.4 \pm 5.1 \mathrm{pCi} / \mathrm{L}$ (table 2 ) and averaged $29.6 \mathrm{pCi} / \mathrm{L}$; the standard error of estimate for the mean concentration was $2.5 \mathrm{pCi} / \mathrm{L}$. Flow from Category I springs contained larger concentrations of tritium than flow from downstream springs. Tritium concentrations in flow from Category I springs ranged from $52.8 \pm 3.2$ to $78.4 \pm 5.1$ $\mathrm{pCi} / \mathrm{L}$ and averaged $62.0 \mathrm{pCi} / \mathrm{L}$ with a standard error of estimate for the mean concentration of $1.3 \mathrm{pCi} / \mathrm{L}$. In contrast, concentrations in flow from Category II springs ranged from $9.2 \pm 0.6$ to $18.5 \pm 1.2$ $\mathrm{pCi} / \mathrm{L}$ and averaged $13.5 \mathrm{pCi} / \mathrm{L}$; the standard error of estimate for the mean concentration was $0.3 \mathrm{pCi} / \mathrm{L}$. Flow from the Category III spring contained smaller concentrations of tritium than Category I springs, and greater concentrations than Category II springs. Tritium concentrations in four water samples

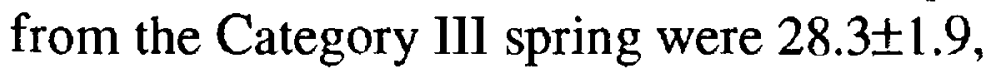
$34.0 \pm 1.9,35.8 \pm 2.6$ and $47.7 \pm 3.2 \mathrm{pCi} / \mathrm{L}$, respectively (table 2 ); the average concentration was $36.4 \mathrm{pCi} / \mathrm{L}$ and the standard error for the mean was $4.1 \mathrm{pCi} / \mathrm{L}$.

Between November 1990 and March 1993, when most of the samples were collected, tritium concentrations generally remained relatively constant or decreased. Concentrations in flow from Blind Canyon and Box Canyon Springs remained relatively constant and the concentrations in flow from the 17 other springs decreased from a minimum of about 8 percent to slightly more than 40 percent.

The differences in tritium concentrations in Category I, II and III springs are a function of the ground-water flow regimes, land uses, and irrigation practices in and hydraulically upgradient from each category of springs. In 1959, Mundorff and others (1964, pl. 4) concluded that part of the ground water discharged to Category I springs originates in areas a few tens of miles east of Twin Falls, near Burley and Lake Walcott; their conclusion was based on a water-table map and a flow-net analysis of the Snake River Plain aquifer. The configuration of the water table in the spring of 1980, as described by Lindholm and others (1988), also supports this conclusion. In contrast, part of the ground water discharged to Category II springs originates in areas near Dubois and Rexburg, about $140 \mathrm{mi}$ northeast of Twin Falls, and part of the water discharged from Category III springs originates in the Big and Little Wood River basins.

Land use along the north side of the Snake River from Lake Walcott to near Crystal Spring largely is irrigated agriculture. Most of the area is irrigated with surface water diverted from the Snake River, although several large acreages are irrigated with ground water (Lindholm and Goodell, 1986). Tritium concentrations in surface-water runoff from rainfall and snowmelt are greater than concentrations in deep ground-water flow systems in which the residence time of water is tens or hundreds of years or more. Rain and snow contain residual concentrations of tritium from atmospheric weapons testing and from natural production, whereas radioactive decay reduces tritium concentrations proportionately with the residence time of water in deep aquifers such as the Snake River Plain aquifer; because of its 12.4-year half-life, about 5.5 percent of tritium radioactively decays annually. For example, the August 1989 water sample collected by the Idaho Department of Health and Welfare from the Snake River contained $300 \pm 200$ pCi/L (U.S. Environmental Protection Agency, 1990, p. 19; see figure 3 for sample- 
collection site). A concentration of $300 \pm 200$ $\mathrm{pCi} / \mathrm{L}$ in water from the Snake River is not unique; from 1974 to 1988 , tritium concentrations ranged from $100 \pm 200$ to $900 \pm 200 \mathrm{pCi} / \mathrm{L}$ (Mann, 1989, p. 19). A sample collected at the gaging station on the Snake River near Buhl (fig. 3) contained $56 \pm 4 \mathrm{pCi} / \mathrm{L}$ in 1993. In contrast, tritium concentrations in spring flow in 1990-93 ranged from $9.2 \pm 0.6$ to $78.4 \pm 5.1 \mathrm{pCi} / \mathrm{L}$.

A large part of the ground-water recharge in irrigated areas along the north side of the Snake River hydraulically upgradient from Category I springs consists of excess appliedirrigation water diverted from the Snake River. Garabedian (1989, pl. 8) estimated that for 1976-80, from 4 to more than 20 in./year of water were recharged to the aquifer in areas where diverted surface water was used for irrigation; in nonirrigated areas, less than 2 in./year of precipitation recharges the aquifer.

Although flow from Category II springs contained detectable concentrations of tritium, the concentrations were less than or equal to $18.5 \pm 1.2 \mathrm{pCi} / \mathrm{L}$ as compared to a minimum of $52.8 \pm 3.2 \mathrm{pCi} / \mathrm{L}$ from Category I springs. Because a large part of the ground water discharged to Category II springs originates $140 \mathrm{mi}$ or more east and northeast of the springs, pre-1950's tritium concentrations may have been a small percentage of the $16 \mathrm{pCi} / \mathrm{L}$ from cosmic-ray production owing to the long residence times of ground water in the aquifer. Tritium in recharge to the aquifer from precipitation and locally, from excessapplied irrigation water diverted from the Snake River would, in turn, increase the concentration of tritium in the flow from Category II springs.

Tritium concentrations in flow from Category III springs are less than those in flow from Category I springs but greater than those in flow from Category II springs. Part of the water discharged to Category III springs originates in the Big and Little Wood River basins (Mundorff and others, 1964, plate 4; and Lindholm and others, 1988); water from the Snake River also is diverted into canals to irrigate crops in areas near Gooding and Shoshone. Flow from Category III springs represents a mix of water, part from recharge in the Big and Little Wood River basins and part from the recharge of water diverted from the Snake River. The fact that tritium concentrations in Category III springs are intermediate to concentrations in Category I and II springs, suggests proportionately different amounts of recharge from excess applied-irrigation water diverted from the Snake River and different ground-water residence times in the aquifer.

Data provided by Wegner and Campbell (1991, table 4) indicate that tritium concentrations in water from wells are relatively consistent with concentrations in spring flow. In 1989, water samples were collected from 50 wells and 5 springs that obtain water from the Snake River Plain aquifer between the southern boundary of the INEL and Hagerman. The water samples were collected as part of a cooperative long-term monitoring program between the USGS, U.S. Department of Energy, and Idaho Department of Water Resources. Tritium concentrations in the 55 water samples ranged from $-12.8 \pm 25.6$ to $134.4 \pm 25.6 \mathrm{pCi} / \mathrm{L}$ (Wegner and Campbell, 1991, table 4); the samples were analyzed using a liquid-scintillation counting method, which has a larger detection limit than the electrolytic-enrichment, gas-counting method. Water samples from wells in areas adjacent to the Snake River from near Rupert to the Category I springs contained more than $30.0 \pm 25.6 \mathrm{pCi} / \mathrm{L}$ of tritium; water from 11 of these wells contained more than 75.0 25.6 $\mathrm{pCi} / \mathrm{L}$. Water samples from most wells in the area from the Category II springs eastward and northeastward to the southern boundary 
of the INEL, contained less than $30.0 \pm 25.6$ $\mathrm{pCi} / \mathrm{L}$. Water from wells east of the Category III springs contained tritium concentrations comparable to concentrations in water from Category I springs.

Data provided by Wegner and Campbell (1991, table 4) also suggest that the tritium concentrations are not uniform with depth in the aquifer. For example, tritium concentrations differed in water from each well in two pairs of wells identified as MV01 and MV02, and MV10 and MV53 (Wegner and Campbell, 1991, fig. 2, and tables 2 and 4); wells in each pair are less than $0.3 \mathrm{mi}$ apart. Wells MV02 and MV53 are comparatively shallow domestic wells, and wells MV01 and MV10 are comparatively deep irrigation wells. The uses of water, depths of wells, and tritium concentrations in the water are shown on the following table:

\begin{tabular}{c} 
Well identifier \\
\hline MV01 \\
MV02 \\
MV10 \\
MV53
\end{tabular}

\begin{tabular}{cc} 
Use of water & $\begin{array}{c}\text { Depth } \\
\text { (feet) }\end{array}$ \\
\hline Irrigation & 217.5 \\
Domestic & 150 \\
Irrigation & 516 \\
Domestic & 350
\end{tabular}

Tritium concentration (picocuries per liter)

$86.4 \pm 25.6$

$48.0 \pm 25.6$

$35.2 \pm 25.6$

$83.2 \pm 25.6$
A comparison of concentrations in water from wells MV01 and MV02 shows that tritium concentrations locally increase with depth in the aquifer. General directions of ground-water flow described by Lindholm and others (1988) show that part of the ground water in the vicinity of these wells originates at or near Lake Walcott about $5 \mathrm{mi}$ to the southeast. Land-use data presented by Lindholm and Goodell (1986) show that ground water is the primary source of irrigation water near wells MV01 and MV02 and between the wells and Lake Walcott.

A comparison of concentrations in water from wells MV10 and MV53 shows that in places tritium concentrations also decrease with depth in the aquifer. General directions of ground-water flow described by Lindholm and others (1988) indicate that part of the water in the vicinity of these wells originates in the area between Burley and Lake Walcott where surface water is the primary source of irrigation water. Irrigation water in the vicinity of this pair of wells, however, is derived from both ground water and surface water, although ground water is the main source. Although data are insufficient to adequately describe the processes that cause increases and decreases of tritium with depth in the aquifer, the data clearly show that recharge from surface water has increased the concentrations of tritium.

\section{SELECTED STABLE ISOTOPES AND NITROGEN}

The conclusion that recharge from excess applied-irrigation water diverted from the Snake River has affected tritium concentrations in the Snake River Plain aquifer is supported by data for selected stable isotopes and concentrations of nitrogenous compounds in spring flow. Wood and Low (1988) showed that recharge from irrigation affected the ratios of two stable isotopes-deuterium $\left({ }^{2} \mathrm{H}\right)$ and oxygen- $18\left({ }^{18} \mathrm{O}\right)$. Data from Brockway and Robison (1992) show that concentrations of nitrite plus nitrate as nitrogen $\left(\mathrm{NO}_{2}+\mathrm{NO}_{3}\right.$ as $\mathrm{N}$ ) in water from some springs have been impacted by agricultural practices. 


\section{Deuterium and Oxygen-18}

Deuterium and ${ }^{18} \mathrm{O}$ are stable isotopes of hydrogen and oxygen. Differences in ${ }^{2} \mathrm{H}$ and ${ }^{18} \mathrm{O}$ ratios for water from springs can be used to identify the source of water discharging from springs. Irrigation recharge is more enriched in ${ }^{2} \mathrm{H}$ and ${ }^{18} \mathrm{O}$ than the regional ground water because of evaporation; therefore, differences in ratios of ${ }^{2} \mathrm{H}$ and ${ }^{18} \mathrm{O}$ indicate whether water from a spring contains a greater portion of irrigation recharge.

Absolute measurement of isotopic ratios is a difficult analytical task; as a result, relative isotopic ratios are measured as a matter of convention (Toran, 1982). For example,

${ }^{18} \mathrm{O} /{ }^{16} \mathrm{O}$ for a sample is compared with ${ }^{18} \mathrm{O} /{ }^{16} \mathrm{O}$ for a standard:

$\delta^{18} \mathrm{O}=\left(\mathrm{R}_{\text {sample }} / \mathrm{R}_{\text {standard }}{ }^{-1}\right) \times 1,000$

where:

$\mathrm{R}_{\text {sample }}={ }^{18} \mathrm{O} /{ }^{16} \mathrm{O}$ in the sample,

$\mathrm{R}_{\text {standard }}={ }^{18} \mathrm{O} /{ }^{16} \mathrm{O}$ in the standards, and

$\delta^{18} \mathrm{O}=$ relative difference in concentration in permil (parts per thousand).

The delta notation $(\delta)$ for example, $\delta^{18} \mathrm{O}$ is the value reported by laboratories for stableisotope analysis. The $\delta^{2} \mathrm{H}$ can be derived by analogy to $\delta^{18} \mathrm{O}$ where the ratio ${ }^{2} \mathrm{H} / \mathrm{H}$ replaces ${ }^{18} \mathrm{O} /{ }^{16} \mathrm{O}$ in $\mathrm{R}_{\text {sample }}$ and $\mathrm{R}_{\text {standard. The }}$ standard used for determining $\delta^{18} \mathrm{O}$ and $\delta^{2} \mathrm{H}$ in water is Vienna Standard Mean Ocean Water (VSMOW) as defined by Craig (1961). The respective precisions of measurement for $\delta^{18} \mathrm{O}$ and $\delta^{2} \mathrm{H}$ at the NWQL are 0.15 permil and 1.5 permil (Ann Mullin, USGS, oral commun., 1991). The ${ }^{2} \mathrm{H}$ and ${ }^{18} \mathrm{O}$ for natural water are commonly reported as negative values when compared to the standard.

Global ${ }^{2} \mathrm{H}$ and ${ }^{18} \mathrm{O}$ ratios for precipitation and freshwater generally lie along a straight line defined as: $\delta^{2} \mathrm{H}=8^{18} \mathrm{O}+10$,

generally referred to as the world meteoric water line (fig. 4). Ratios for precipitation and freshwater near coastal areas also generally lie along this line. Because inland-continental freshwater generally undergoes greater evaporation, the slope of the meteoric water line is less than 8 (Gat and Gonfiantini, 1981, p. 132). The local surface-water meteoric line for the Snake River Plain is defined as:

$\delta^{2} \mathrm{H}=6.4 \delta^{18} \mathrm{O}-21$ Wood and Low, 1988, p. 15).

Deuterium and ${ }^{18} \mathrm{O}$ ratios for water from selected springs lie near the local meteoric water line, indicating that prior to recharge, the spring water is derived from local surface water (fig. 4). Stable-isotopic ratios for water from selected springs are shown on table 3 .

Stearns and others (1938, p. 62) and Mundorff and others (1964, p. 172) concluded that recharge to springs (Category I) between Twin Falls and Buhl mostly is derived from local irrigation. Water from Blue Lakes and Crystal Springs (Category I) contains a greater portion of irrigation recharge than water from Briggs, Box Canyon, Blue Heart, and Sand Springs (Category II), which are farther downstream. Wood and Low (1988, p. 31) contrasted ${ }^{2} \mathrm{H}$ and ${ }^{18} \mathrm{O}$ ratios for water from Blue Lakes Spring and the regional ground water and argued that the isotopically-enriched water from Blue Lakes Spring is the result of irrigation recharge mixing with the regional ground water. The average of $15^{2} \mathrm{H}$ and ${ }^{18} \mathrm{O}$ samples from Box Canyon Springs (Category II) was -137.2 permil and -17.9 permil, respectively; the average from Blue Lakes Spring was -131.7 permil and -16.9 permil, respectively. The Box Canyon Springs ratios compare closely with the regional ground water average of -136.4 permil for ${ }^{2} \mathrm{H}$ and -17.7 permil for ${ }^{18} \mathrm{O}$, whereas, water from Blue Lakes Spring are enriched (Wood and Low, 1988, p. 31). Water from Category I 


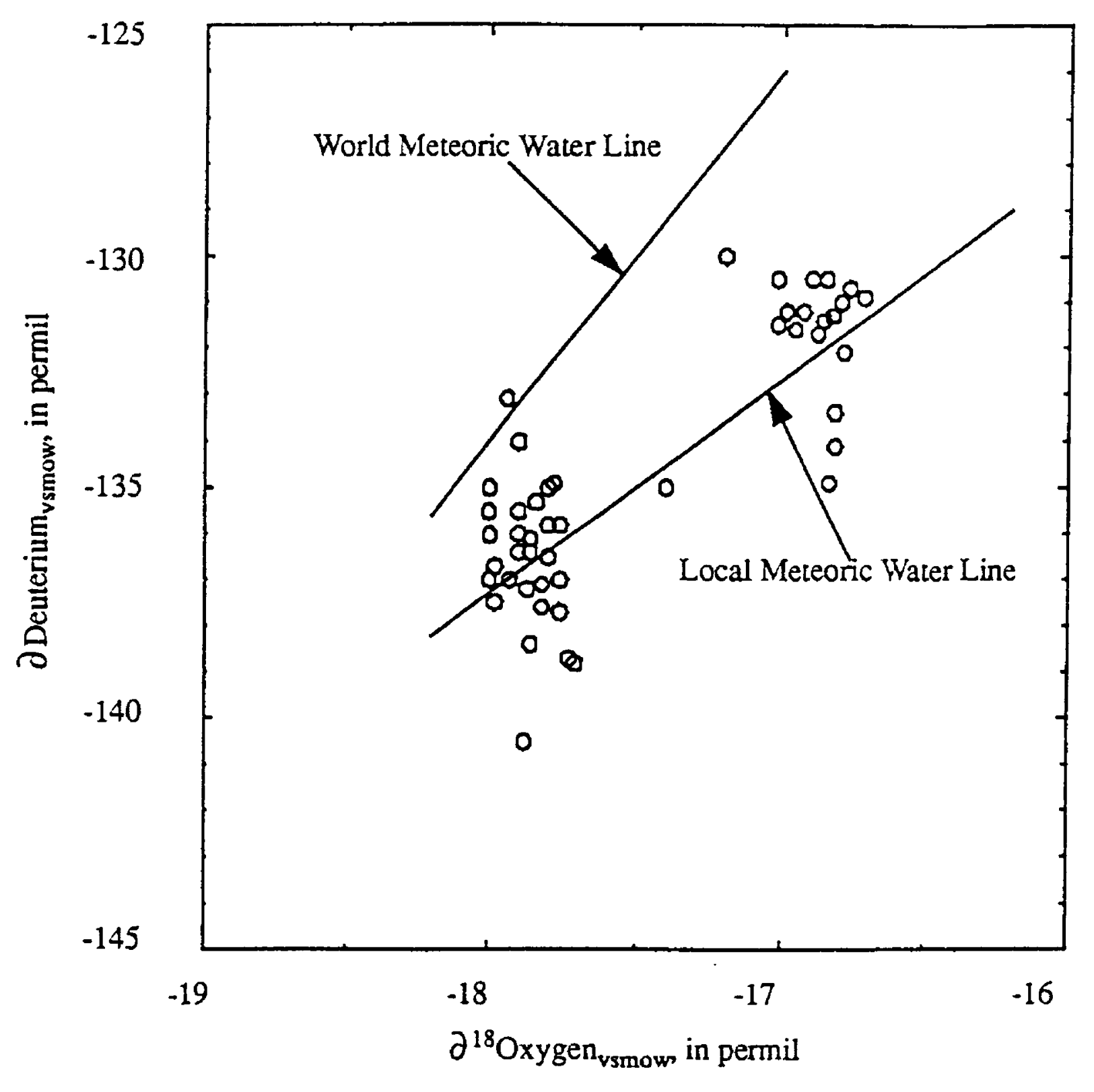

Figure 4. Deuterium and oxygen-18 isotopic ratios in water from selected springs, Twin Falls-Hagerman area, Idaho. 
Table 3.-Stable-isotope ratios in water from selected springs, Twin Falls-Hagerman area, Idaho

[See figure 3 for location of springs and table 1 for their downstream order. Deuterium, permil VSMOW; oxygen-18, permil VSMOW]

\begin{tabular}{llll}
\hline Name of spring(s) & Date sampled & $\delta$ deuterium & $\delta$ oxygen-18
\end{tabular}

\begin{tabular}{|c|c|c|c|}
\hline \multirow[t]{3}{*}{ Blue Heart } & $12 / 6 / 84$ & -135.8 & -17.8 \\
\hline & $8 / 22 / 86$ & -134.0 & -17.9 \\
\hline & $3 / 17 / 87$ & -135.0 & -18.0 \\
\hline \multirow{15}{*}{ Blue Lakes } & $11 / 5 / 80$ & -131.0 & -17.2 \\
\hline & $3 / 20 / 85$ & -130.7 & -16.8 \\
\hline & $3 / 19 / 87$ & -129.5 & -17.0 \\
\hline & $3 / 12 / 84$ & -131.7 & -16.9 \\
\hline & $7 / 2 / 84$ & -131.6 & -17.0 \\
\hline & $8 / 20 / 84$ & -134.1 & -16 \\
\hline & $10 / 2 / 84$ & -134.9 & -16 \\
\hline & $12 / 5 / 84$ & -130.5 & -16.9 \\
\hline & $1 / 17 / 85$ & -131.4 & -16.9 \\
\hline & $5 / 9 / 85$ & -131.2 & -16.9 \\
\hline & $7 / 1 / 85$ & -131.2 & -17.0 \\
\hline & $8 / 6 / 85$ & -133.4 & -16.8 \\
\hline & $9 / 16 / 85$ & -131.3 & -16.8 \\
\hline & $10 / 21 / 85$ & -131.5 & -17.0 \\
\hline & $11 / 25 / 85$ & -132.1 & -16.8 \\
\hline \multirow[t]{15}{*}{ Box Canyon } & $11 / 7 / 80$ & -137.0 & -18.0 \\
\hline & $3 / 13 / 84$ & -137.6 & -17 \\
\hline & $7 / 17 / 84$ & -137.5 & -18.0 \\
\hline & $8 / 28 / 84$ & -138.7 & -17.7 \\
\hline & $10 / 3 / 84$ & -138.4 & -17.9 \\
\hline & $12 / 7 / 84$ & -140.5 & -17.9 \\
\hline & $1 / 18 / 85$ & -137.1 & -17.8 \\
\hline & $3 / 21 / 85$ & -137.0 & -17.8 \\
\hline & $5 / 9 / 85$ & -137.2 & -17.9 \\
\hline & $7 / 1 / 85$ & -136.4 & -17 \\
\hline & $8 / 6 / 85$ & -136.4 & -17.9 \\
\hline & $9 / 12 / 85$ & -137.0 & -17.9 \\
\hline & $10 / 21 / 85$ & -136.4 & -17 \\
\hline & $11 / 25 / 85$ & -134.9 & $-1^{\prime}$ \\
\hline & $3 / 17 / 87$ & -135.5 & -18 \\
\hline
\end{tabular}


Table 3.-Stable-isotope ratios in water from selected springs, Twin Falls-Hagerman area, Idaho-continued

\begin{tabular}{lccc}
\hline Name of spring(s) & Date sampled & $\delta$ deuterium & $\delta$ oxygen-18 \\
\hline \multirow{3}{*}{ Briggs Creek } & & & \\
& $11 / 5 / 80$ & -136.0 & -17.9 \\
& $3 / 13 / 84$ & -135.3 & -17.8 \\
& $12 / 3 / 84$ & -137.7 & -17.8 \\
& $3 / 21 / 85$ & -136.1 & -17.9 \\
& $11 / 13 / 85$ & -135.8 & -17.8 \\
& $3 / 17 / 87$ & -135.5 & -18.0 \\
Crystal & & & -17.0 \\
& $3 / 20 / 85$ & -130.5 & -16.8 \\
& $11 / 13 / 85$ & -130.9 & -17.2 \\
Sand & $3 / 18 / 87$ & -130.0 & -18.0 \\
& & & -17.7 \\
& $11 / 3 / 80$ & -137.0 & -18.0 \\
& $3 / 12 / 84$ & -138.8 & -17.9 \\
& $3 / 18 / 85$ & -136.7 & -18.0 \\
\hline
\end{tabular}

springs are more enriched in ${ }^{2} \mathrm{H}$ and ${ }^{18} \mathrm{O}$ and ratios of ${ }^{2} \mathrm{H}$ and ${ }^{18} \mathrm{O}$ plot higher along the local meteoric line that ratios for Category II springs. These differences in ratios show that springs in Category I have a greater proportion of irrigation recharge than springs in Category II.

\section{Nitrite Plus Nitrate as Nitrogen}

Concentrations of $\mathrm{NO}_{2}+\mathrm{NO}_{3}$ as $\mathrm{N}$ commonly indicate water pollution caused by activities such as irrigated agriculture, sewage treatment, and livestock feedlots. Brockway and Robison (1992) presented concentrations of $\mathrm{NO}_{2}+\mathrm{NO}_{3}$ as $\mathrm{N}$ in water from some of the springs for which tritium concentrations have been determined. Concentrations of $\mathrm{NO}_{2}+\mathrm{NO}_{3}$ as $\mathrm{N}$ in water from two Category I springs-Devils Corral and Warm Creek- were greater than those in water from four Category II springs-Banbury, Blind Canyon, Clear Lakes, and Riley Creek. Concentrations of $\mathrm{NO}_{2}+\mathrm{NO}_{3}$ as $\mathrm{N}$ in three samples from Category 1 springs ranged from 2.050 to $3.100 \mathrm{mg} / \mathrm{L}$ (table 4). In contrast, concentrations of $\mathrm{NO}_{2}+\mathrm{NO}_{3}$ as $\mathrm{N}$ in 55 samples from Category II springs ranged from 0.060 to $2.060 \mathrm{mg} / \mathrm{L}$ and averaged $1.09 \mathrm{mg} / \mathrm{L}$.

Brockway and Robison (1992, p. 66-67) concluded that the "average seasonal concentration of nutrients in the main [Snake] river reflect the locations of nutrient inflows as well as the inflow of spring water from the Snake [River] Plain aquifer. Average $\mathrm{NO}_{2}+\mathrm{NO}_{3}$ as $\mathrm{N}$ concentrations increase from approximately $1 \mathrm{mg} / \mathrm{L}$ at Milner to over $1.6 \mathrm{mg} / \mathrm{L}$ from Twin Falls Pool to Clear Lakes Bridge. The $\mathrm{NO}_{2}+\mathrm{NO}_{3}$ as $\mathrm{N}$ level 
decreases and remains relatively constant at about $1.4 \mathrm{mg} / \mathrm{L}$ from Clear Lakes to King Hill***Tributary stream nutrient load levels reflect integrated effects of surface irrigation return flow, ground-water returns, and aquacultural activities but show significant increases in suspended solids during the irrigation season." Tributary streams as defined by Brockway and Robison (1992) include those springs listed on table 4 .

\section{SUMMARY}

Concern has been expressed that some of the approximately $31,000 \mathrm{Ci}$ of tritium in wastewater discharged to the Snake River Plain aquifer from 1952 to 1990 at the INEL has migrated or will migrate to the Snake River in the Twin Falls-Hagerman area. Analyses of samples collected in 1990-93 from 19 springs on the north side of the Snake River will serve as a baseline to quantitatively document whether tritiated water disposed to the aquifer at the INEL has a measurable long-term effect on tritium concentrations in spring flow.
Tritium, a naturally occurring isotope of hydrogen with a 12.4-year half-life, also is a radioactive waste product from nuclear powerplant operations, fuel processing, and weapons production and testing. Tritium concentrations in surface water in the United States increased from less than $16 \mathrm{pCi} / \mathrm{L}$ in the 1950 's to about $3,500 \mathrm{pCi} / \mathrm{L}$ in 1963 owing to atmospheric testing of nuclear weapons.

In 1990-93, tritium concentrations in the flow of the 19 springs ranged from $9.2 \pm 0.6$ to $78.4 \pm 5.1 \mathrm{pCi} / \mathrm{L}$. On the basis of their locations and tritium concentrations, the springs were placed into three categories: Category I springs are the farthest upstream and contained from $52.8 \pm 3.2$ to $78.4 \pm 5.1 \mathrm{pCi} / \mathrm{L}$ of tritium; Category II springs are downstream from those in Category I and contained from $9.2 \pm 0.6$ to $18.5 \pm 1.2 \mathrm{pCi} / \mathrm{L}$ of tritium; and Category III springs are the farthest downstream and contained from $28.3 \pm 1.9$ to $47.7 \pm 3.2 \mathrm{pCi} / \mathrm{L}$.

Differences in the tritium concentrations in the Category I, II, and III springs are a

\section{Table 4.-Concentrations of nitrite plus nitrate as nitrogen in water from selected springs, Twin Falls-Hagerman area, Idaho}

[From Brockway and Robison, 1992, appendices C and D]

\begin{tabular}{lcccc}
\hline Name of spring(s) & \multirow{2}{*}{$\begin{array}{c}\text { Number } \\
\text { of samples }\end{array}$} & \multicolumn{3}{c}{ Concentration (milligrams per liter) } \\
\cline { 3 - 5 } & & Minimum & Maximum & Mean \\
\hline Banbury & 1 & .992 & .992 & -- \\
Blind Canyon & 26 & .060 & 1.300 & .588 \\
Clear Lakes & 27 & .667 & 2.060 & 1.583 \\
Devils Corral & 1 & 2.050 & 2.050 & - \\
Riley Creek & 1 & .716 & .716 & -- \\
Warm Creek & 2 & 2.390 & 3.100 & 2.745 \\
\hline
\end{tabular}


function of the ground-water flow regimes, land uses, and irrigation practices in and hydraulically upgradient from each category of springs. Part of the ground water discharged to Category I springs originates a few tens of miles east of Twin Falls. In contrast, part of the ground water discharged to Category II springs originates about $140 \mathrm{mi}$ northeast of Twin Falls and part of the ground water that discharged to Category III springs originates in the Big and Little Wood River basins. A large part of the ground-water recharge in irrigated areas hydraulically upgradient from Category I springs consists of excess applied-irrigation water diverted from the Snake River. It is estimated that in areas where diverted surface water was used for irrigation for 1976-80, from 4 to more than $20 \mathrm{in./year}$ of irrigation water recharged the aquifer; in nonirrigated areas, less than $2 \mathrm{in}$./year of precipitation recharged the aquifer.

Because a large part of the ground water discharged to Category II springs originates up to $140 \mathrm{mi}$ or more to the east and northeast, and because of the long residence time in the aquifer, concentrations of tritium in Category II springs are smaller than concentrations in Category I springs. The fact that tritium concentrations in Category III springs are intermediate to concentrations in Category I and II springs suggests proportionately different amounts of recharge from excess applied-irrigation water diverted from the Snake River and different residence times of ground water in the aquifer.

The conclusion that recharge from excess applied-irrigation water diverted from the Snake River has affected tritium concentrations in the Snake River Plain aquifer is supported by differences in the $\delta^{18} \mathrm{O}$ and $\delta^{2} \mathrm{H}$ ratios of water from springs. These differences indicate that the springs are recharged by water from different origins. Irrigation recharge is more enriched in ${ }^{2} \mathrm{H}$ and ${ }^{18} \mathrm{O}$ than the regional ground water. Water from Category I springs is more enriched in ${ }^{2} \mathrm{H}$ and ${ }^{18} \mathrm{O}$ than water from Category II and III springs because a large proportion of irrigation recharge mixes with the regional ground water in Category I springs. Concentrations of $\mathrm{NO}_{2}+\mathrm{NO}_{3}$ as $\mathrm{N}$ are greater in water from Category I springs than in water from Category II springs because of the integrated effects of irrigation and aquacultural activities.

\section{REFERENCES CITED}

Brockway, C.E., and Robison, C.W., 1992, Middle Snake River water quality study, phase 1 , final report: Moscow, University of Idaho, Water Resources Research Institute, 70 p., 10 apps.

Craig, Harmon, 1961, Isotopic variations in meteoric waters: Science, v. 133, p. 1,702-1,703.

Garabedian, S.P., 1986, Application of a parameterestimation technique to modeling the regional aquifer underlying the eastern Snake River Plain, Idaho: U.S. Geological Survey Water-Supply Paper 2278, $60 \mathrm{p}$.

-.-- 1989, Hydrology and digital simulation of the regional aquifer, eastern Snake River Plain, Idaho: U.S. Geological Survey Open-File Report 87-237, $151 \mathrm{p}$.

Gat, J.R., and Gonfiantini, R., eds., 1981, Stable isotope hydrology-deuterium and oxygen-18 in the water cycle: International Atomic Energy Agency, Technical Reports Series no. 210, 339 p.

Kjelstrom, L.C., 1992, Streamflow gains and losses in the Snake River and ground-water budgets for the Snake River Plain, Idaho and eastern Oregon: U.S. Geological Survey Open-File Report 90-172, 71 p.

Lindholm, G.F., Garabedian, S.P., Newton, G.D., and Whitehead, R.L., 1988, Configuration of the water table and depth to water, spring 1980, water-level fluctuations, and water movement in the Snake River Plain regional aquifer system. Idaho and eastern Oregon: U.S. Geological Survey Hydrologic Investigations Atlas HA-703, 1 sheet, scale 1:500,000. 
Lindholm, G.F., and Goodell, S.A., 1986, Irrigated acreage and other land uses on the Snake River Plain, Idaho and eastern Oregon: U.S. Geological Survey Hydrologic Investigations Atlas HA-691, 1 sheet, scale 1:500,000.

Mann, L.J., 1989, Tritium concentrations in flow from selected springs that discharge to the Snake River, Twin Falls-Hagerman area, Idaho: U.S. Geological Survey Water-Resources Investigations Report 89$4156,20 \mathrm{p}$.

Mann, L.J., and Cecil, L.D., 1990, Tritium in ground water at the Idaho National Engineering Laboratory, Idaho: U.S. Geological Survey WaterResources Investigations Report 90-4090, 35 p.

Michel, R.L., 1989, Tritium deposition in the continental United States, 1953-83: U.S. Geological Survey Water-Resources Investigations Report 89-4072, 46 p.

Moreland, J.A., 1976, Digital-model analyses of the effects of water-use alternatives on spring discharges, Gooding and Jerome Counties, Idaho: Idaho Department of Water Resources Water Information Bulletin No. 42, 46 p.

Mundorff, M.J., Crosthwaite, E.G., and Kilburn, Chabot, 1964, Ground water for irrigation in the Snake River Basin in Idaho: U.S. Geological Survey Water-Supply Paper 1654, 224 p.

National Council on Radiation Protection and Measurements, 1979, Tritium in the environment: National Council on Radiation Protection and Measurements Report No. 62, 125 p.

Orr, B.R., and Cecil, L.D., 1991, Hydrologic conditions and distribution of selected chemical constituents in water, Snake River Plain aquifer, Idaho National Engineering Laboratory, Idaho, 1986 to 1988: U.S. Geological Survey Water-Resources Investigations Report 91-4047, 56 p.

Pittman, J.R., Jensen, R.J., and Fischer, P.R., 1988, Hydrologic conditions at the Idaho National Engineering Laboratory, 1982 to 1985: U.S. Geological Survey Water-Resources Investigations Report 89-4008, 73 p.

Pritt, Jeffrey, and Jones, B.E., eds., 1989, 1990 National Water Quality Laboratory services catalog: U.S. Geological Survey Open-File Report 89-386, [variously paged].
Skougstad, M.W., Fishman, M.J., Friedman, L.C., Erdmann, D.E., and Duncan, S.S., eds., 1979, Methods for determination of inorganic substances in water and fluvial sediments: U.S. Geological Survey Techniques of Water-Resources Investigations, book 5 , chap. A1, $626 \mathrm{p}$.

Stearns, H.T., Crandall, Lynn, and Steward, W.G., 1938, Geology and ground-water resources of the Snake River Plain in southeastern Idaho: U.S. Geological Survey Water-Supply Paper 774, $268 \mathrm{p}$.

Thatcher, L.L., Janzer, V.J., and Edwards, K.W., 1977, Methods for determination of radioactive substances in water and fluvial sediments: U.S. Geological Survey Techniques of WaterResources Investigations, book 5, chap. A5, 95 p.

Toran, Laura, 1982, Isotopes in ground-water investigations: Ground Water, v. 20, no. 6 , p. 740-745.

U.S. Environmental Protection Agency, 1983, Protection of environment, Subpart B of Part 141: U.S. Code of Federal Regulations, Title 40, Parts $100-149$, revised as of July $1,1983,399 \mathrm{p}$.

---- 1990, Environmental radiation data, JulySeptember 1989: U.S. Environmental Protection Agency Report No. 59, 46 p.

Wegner, S.J., and Campbell, L.J., 1991, Radionuclides, chemical constituents, and organic compounds in water from designated wells and springs from the southern boundary of the Idaho National Engineering Laboratory to the Hagerman Area, Idaho, 1989: U.S. Geological Survey Open-File Report 91-232, $49 \mathrm{p}$.

Wood, W.W., 1976, Guidelines for collection and field analysis of ground-water samples for selected unstable constituents: U.S. Geological Survey Techniques of Water-Resources Investigations, book 1 , chap. D2, $24 \mathrm{p}$.

Wood, W.W., and Low, W.H., 1988, Solute geochemistry of the Snake River Plain regional aquifer system, Idaho and eastern Oregon: U.S. Geological Survey Professional Paper 1408-D, $79 \mathrm{p}$.

Young, H.W., and Newton, G.D., 1989, Hydrology of the Oakley Fan area, south-central Idaho: U.S. Geological Survey Water-Resources Investigations Report 88-4065, 73 p. 